OBITUARY

\title{
Martin Fuchsberger
}

Professor Martin Fuchsberger was born on 28 February 1924 in Ebenau near Salzburg. He passed away peacefully on 12 November 2015 at his home in Hausmannstätten near Graz.

After finishing high school, the Second World War did not allow him to enter university immediately after school, but forced him to serve in the army fighting at the Russian front. In 1945, he started his studies in civil engineering at the Technical University of Graz where he completed his masters degree in 1951. After working in consultancy for some time he returned to academia, working as research assistant of Professor Osterberg at Northwestern University in Illinois, USA, where he obtained a Master of Science in soil mechanics. He then remained in the USA, working on frost susceptibility of soils with the U.S. Army Corps of Engineers. For personal reasons he returned to Austria in 1958 and worked with Professors Fröhlich and Veder on various practical projects.

In 1959 Professor Fuchsberger joined the specialist contractor Impresa di Costruzione Opere Specializzate (I.C.O.S.), first in Milan and from 1962 onwards in the UK, where he was soon promoted to general manager. He was involved in some of the earliest structural diaphragm walls in the UK, including those at Hyde Park Corner and Brittanic House, and many other complex geotechnical projects, including some of the first cement-bentonite cut-off walls in the UK. He worked in the UK for 20 years during which time he became an internationally recognised expert on diaphragm wall techniques.

In 1982 he was appointed Professor at the Institute for Soil Mechanics, Rock Mechanics and Foundation Engineering at the Technical University of Graz, which was founded by Professor Veder in 1964. The presentation by Professor Fuchsberger at his selection committee demonstrating the novel approach of prestressing diaphragm walls is still vividly remembered. His practical experience was the driving force in teaching students at the university and even after retiring in 1993 he continued to give lectures at the Universities of Timisoara and Cluj-Napoca in Romania. Despite being based full time in Graz, he never lost his contacts with the $\mathrm{UK}$, and in this way he opened the door for young academics

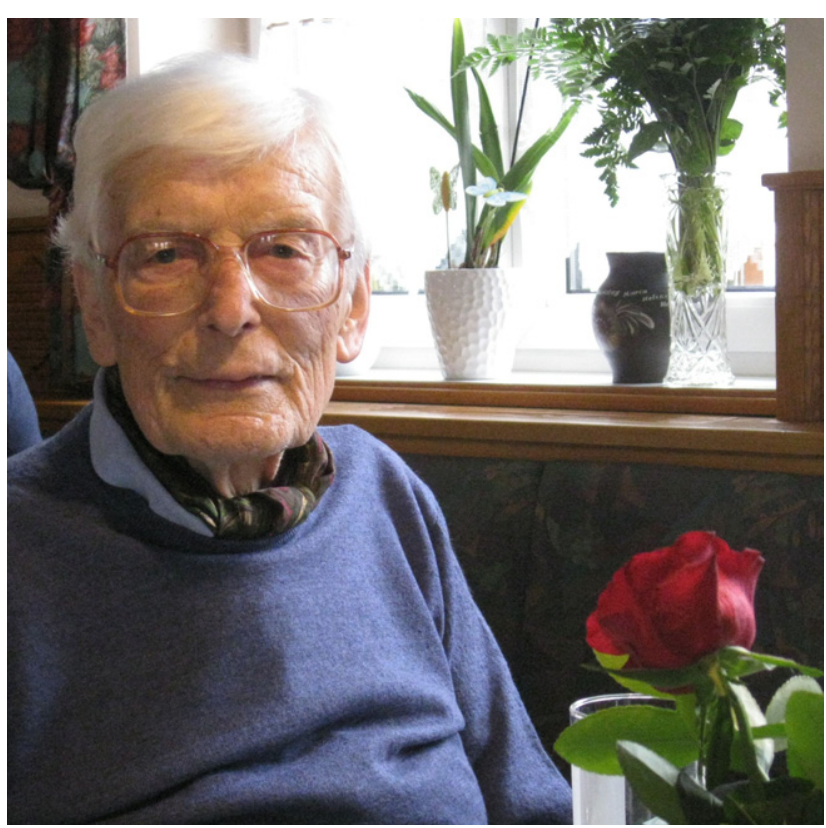

Martin Fuchsberger (1924-2015)

to the international scientific community in soil mechanics and foundation engineering. His international network enabled research assistants and students to visit exceptional geotechnical projects, and participants of excursions to England and Italy still remember these as professional highlights.

With the passing of Professor Fuchsberger the geotechnical community has lost a highly respected engineer, who in addition to his professional wisdom, surprised many by his profound general knowledge of history, geography and the arts. All who spent time with Professor Fuchsberger remember his charming personality and the pleasure of working with him.

H. F. Schweiger, Graz University of Technology, Graz, Austria S. A. Jefferis, Environmental Geotechnics Ltd, Banbury, UK 